Research Article

\title{
Preliminary pharmacological investigation of the ischuretic property and safety of a hydro-ethanolic extract of Amaranthus spinosis (Fam: Amaranthaceae)
}

\author{
George A. Koffuor ${ }^{1}$, George K. Ainooson ${ }^{1}$, John N. A. Addotey ${ }^{2}$, \\ Isaac K. Amponsah ${ }^{3}$, Victor A. Afriyie ${ }^{1}$, Rockson Tutu ${ }^{1}$
}

${ }^{1}$ Department of Pharmacology,

${ }^{2}$ Department of Pharmaceutical

Chemistry, ${ }^{3}$ Department of

Pharmacognosy, Faculty of

Pharmacy and Pharmaceutical

Sciences, Kwame Nkrumah

University of Science and

Technology, Kumasi, Ghana

Received: 12 July 2013

Accepted: 22 July 2013

*Correspondence to:

Dr. George A. Koffuor,

Email: gkoffuor@yahoo.com

(C) 2013 Koffuor GA et al. This is an open-access article distributed under the terms of the Creative Commons Attribution NonCommercial License, which permits unrestricted noncommercial use, distribution, and reproduction in any medium, provided the original work is properly cited.

\begin{abstract}
Background: Ischuria is a health and social problem, having a negative impact on sufferers. This study therefore was a preliminary investigation of the ischuretic property and safety for use of a hydro-ethanolic extract of Amaranthus spinosus used traditionally in managing ischuria.

Methods: Phytochemical screening, thin layer chromatography and high performance liquid chromatography were performed on the extract to establish fingerprints for identification. Acetylcholine, Nicotine, and the extract were applied to an isolated rat urinary bladder to ascertain contractile response. The possible receptor site(s) of action was also investigated using isolated rabbit jejunum, and guinea-pig ileum preparations. In-house observation, hematological analysis, and liver and kidney function tests were performed on Sprague-Dawley rats, in acute and sub-acute toxicity studies.

Results: The extract had contractile effects on the rat urinary bladder (similar to acetylcholine and nicotine) and rabbit jejunum. Its contractile effect of the guinea-pig ileum was significantly inhibited by hexamethonium $(77.50 \pm 8.50$ $\% ; P \leq 0.001)$ and to a lesser extent by mepyramine $(49.2 \pm 6.80 \% ; P \leq 0.001)$ and Atropine $(22.45 \pm 5.22 \% ; P \leq 0.01)$. The extract $\left(80-800 \mathrm{mg} \mathrm{kg}^{-1}\right)$ was not lethal and a 160 and $240 \mathrm{mg} \mathrm{kg}^{-1}$ dose had no adverse effect on blood, liver, kidney metabolic function.

Conclusions: The hydro-ethanolic extract of Amaranthus spinosus has ischuretic activity possibly mediated via nicotinic, histaminic and muscarinic receptor stimulation and is safety to use in ischuria.
\end{abstract}

Keywords: Ischuria, Muscarinic receptors, Nicotinic receptors, Ganglion stimulant, Detrusor smooth muscle, Histaminic effect

\section{INTRODUCTION}

Ischuria or urinary retention is the inability to voluntarily void urine or empty the bladder fully. It is a health and social problem, having a negative impact on people who suffer from it. ${ }^{1}$ Ischuria can be an acute or a chronic disorder of the urinary system. Studies indicate that men aged 70 to 79 have a $10 \%$ risk of developing acute urinary retention. The risk increases to 1 in 3 for men in their $80 \mathrm{~s}^{2}$ It is estimated that in the USA overall occurrence was 4.5 to 6.8 for 1000 men in ages between 40 and 83 years. A study in Denmark by Glavind et al.,
$2003^{3}$ shows that urinary retention postpartum has an incidence rate of $0.7 \%$ of birth deliveries recorded.

Benign prostatic hyperplasia is one of the most common causes of ischuria. Other causes may be acute prostatitis, obstruction or blockade due to bladder stones, medication use, trauma, herniation, stroke, diabetes neuropathy, use of anti-cholinergics and alpha adrenergic agents among others. ${ }^{4}$ In women, the regular cause of ischuria is a primary disorder of sphincter relaxation also known as Fowler's syndrome. ${ }^{5}$ A study by Grosshans et al., $1993^{6}$ also found that psychological dependence and functional confines in the elderly also can cause ischuria. Prostatic 
infarctions may also cause neurologic disturbance, inhibiting relaxation of the prostatic urethra or to swelling or rise in prostatic pressure leading to ischuria. ${ }^{7}$

Acute ischuria comes with discomfort, and pain, bloated abdomen, the urge to urinate but inability to do so, weak urine flow, and difficulty in fully emptying bladder. ${ }^{8}$ Complications including bladder and urinary tract infections, bladder damage and chronic kidney disease may arise if ischuria is not managed. Management requires urgent catheterization. A surgical procedure may also be employed in prostate cancer or for women with a fallen bladder. ${ }^{7}$

The non-pharmacological management of ischuria involving surgery presents a source of worry and anxiety to most patients. Pharmacological management with orthodox medicines is however expensive. Moreover, management may require a hospital or clinical setup which is either unavailable or unaffordable in rural communities. It is in this light that new ways of treatment/management of ischuria is being sought for.

Amaranthus spinosus (Family: Amaranthaceae) is used locally in Ghana to manage of acute urinary retention. ${ }^{9}$ Non-pharmacologically, it serves as forage for cattle and it is believed it increases the yield of milk in cattle. ${ }^{10}$ In Uganda, the ash is burnt and used to make tough vegetables like cowpea leaves tender during cooking. The ash is also used in southern Africa as a snuff alone or with tobacco. ${ }^{11}$ Pharmacologically, it has been found to possess anti-inflammatory, and central and peripheral analgesic activity. ${ }^{12}$ It also has immunostimulatory activity. ${ }^{13}$ The leaves can be used as an anti-inflammatory agent. ${ }^{14}$ Medicinally, the whole plant can also be used as a laxative and in asthma as a bronchodilator. ${ }^{15}$ In south East Asia a decoction of the root is used to treat gonorrhea and also applied as an emenagogue and as an antipyretic. ${ }^{14}$ In Africa, the bruised leaves are considered a good emollient and applied externally in cases of eczema, burns, wounds, boils, and haemorrhoids. ${ }^{11}$

This study therefore was a preliminary pharmacological investigation to validate the use of Amaranthus spinosus as an ischuretic in the management of ischuria in Ghana, to determine the possible receptors mediating its ischuretic activity, and to ascertain its safety for use.

\section{METHODS}

\section{Collection of Plant}

Fresh whole plants of Amaranthus spinosus were collected from Ayeduase, a surburb of Kumasi, in the Ashanti Region of Ghana, in November, 2012, by Madam Mary Margaret Darkwah Panyin, a Herbalist. The plant was authenticated at the Department of Herbal Medicine, FPPS, CHS, KNUST, Kumasi, Ghana where a voucher specimen with number KNUST/HM1/2012/S011 has been deposited.

\section{Preparation of Hydro-ethanolic whole Plant Extract}

Amaranthus spinosus (whole plant) was sun-dried and milled with a hammer mill (Schutte Buffalo, New York, USA). A $1.1 \mathrm{~kg}$ quantity of the powder was soxhletextracted with 2 liters of $70 \%$ ethanol for $24 \mathrm{~h}$. The extract obtained was evaporated to dryness on a water bath maintained at $60^{\circ} \mathrm{C}$. The dried extract weighing $130 \mathrm{~g}$ (Percentage yield: $11.8 \%$ ) was labeled EAS for use in this study.

\section{Experimental Animals}

Male Sprague-Dawley rats (200-220 g), purchased from the Centre for Scientific Research into Plant Medicine, Mampong-Akwapim, Ghana, were maintained in the Animal House of Department of Pharmacology, KNUST, Ghana. The animals were housed in polyacrylic cages $(34 \mathrm{~cm} \times 47 \mathrm{~cm} \times 18 \mathrm{~cm})$ with soft wood shaving as bedding, under ambient laboratory conditions (temperature $28 \pm 2{ }^{\circ} \mathrm{C}$, relative humidity $60-70 \%$, and normal light-dark cycle). They were fed with normal commercial pellet diet (GAFCO, Tema) water ad libitum. All procedures and techniques used in these studies were in accordance with the National Institute of Health for the Care and Use of Laboratory Animals. Protocols for the study were approved by the Departmental Ethics Committee.

\section{Chemicals Used}

Acetylcholine, Nicotine, and Histamine were used as reference agonists, while Atropine, Mepyramine, and Hexamethonium were used as reference antagonists in the study. These drugs were obtained from SigmaAldrich, USA. Phenobarbitone (BDH chemicals Ltd, Poole, England) was used as an anesthetic agent during the preparation of the rat bladder for isolation.

\section{Preliminary Phytochemical Screening}

EAS was subjected to phytochemical screening for the presence of secondary metabolites in accordance with the standard procedure described by Wagner and Bladt (1996), ${ }^{16}$ Harborne (1998), ${ }^{17}$ and Kujur et al., (2010). ${ }^{18}$

\section{Thin-Layer Chromatography}

Aluminium precoated silica gel plates 60 F254 $(0.25 \mathrm{~mm}$ thick) was cut to an appropriate size so as to fit in a chromatank. EAS (5 mg) was constituted in ethanol (95\%) and applied on the TLC plates as spots with the aid of capillary tubes at one end of the plate in a straight line about $2 \mathrm{~cm}$ above the edge and $1.5 \mathrm{~cm}$ away from the margins. The spots were dried and the plates placed inside a chromatank saturated with the mobile phase; a mixture of chloroform and methanol in the ratio 93:7. The one way ascending technique was used to develop the plate. The zones on TLC plates corresponding to separated compounds were detected under UV light 254 
$\mathrm{nm}$ and also by spraying with anisaldehyde $0.5 \% \mathrm{~W} / \mathrm{V}$ in $\mathrm{HOAC} / \mathrm{H} 2 \mathrm{SO} 4 / \mathrm{MeOH}$ (10:5:85) followed by heating at $105^{\circ} \mathrm{C}$ for $5-10 \mathrm{~min}$.

\section{High Performance Liquid Chromatography (HPLC) Analysis}

Approximately $2 \mathrm{ml}$ of a $0.1 \% \mathrm{w} / \mathrm{v}$ ethanolic (absolute) solution of EAS was transferred into a $1 \mathrm{~cm}$ thick cuvette and placed in a double beam UV machine (T90 + UV/Visible Spectrophotometer, PG Instruments Ltd., UK) to obtain a UV/Visible spectrum. The wavelength of maximum absorption was selected from the spectrum and used as the wavelength for the HPLC determination. The HPLC set up consisted of an LC-10AD Shimadzu pump (Shimadzu Corporation, Kyoto, Japan) connected to a Perkin Elmer 785A UV/Visible detector (Perkin Elmer Inc., USA), using a phenyl column (Zorbax, $3.0 \times 150 \mathrm{~mm}$ x 3.5 microns) and methanol:water (50:50) as the stationary phase and mobile phase respectively. A $20 \mu \mathrm{L}$ quantity of the sample was analyzed isocratically at a wavelength of $254 \mathrm{~nm}$ (flow rate of $1 \mathrm{ml} \mathrm{min}^{-1}$ ) and a chromatogram obtained.

\section{Effect of EAS on Isolated Rat Bladder}

The rat bladder was isolated as described by Saito and Miyagawa (2001). ${ }^{19}$ A male Sprague-Dawley rat weighing $175 \mathrm{~g}$ was obtained from the Departmental Animal house was anesthetized by injecting phenobarbital (50 $\mathrm{mg} \mathrm{kg}^{-1}$ i.p). The penile urethra was clamped with a small clip. A cystosomy was created and about $3 \mathrm{ml}$ of saline was infused to induced acute urinary retention. At $30 \mathrm{~min}$ of induction of the urinary retention, the cystosomy was opened to isolate the bladder. Smooth muscle strips of the bladder were obtained after the removal and kept in Krebs solution.

A strip of the rat bladder was mounted in $10 \mathrm{ml} \mathrm{Kreb's}$ solution maintained at $37^{\circ} \mathrm{C}$ in a Harvard tissue bath (Harvard Apparatus Ltd, Kent, UK). The tissue was constantly aerated and made to stabilize for about $15 \mathrm{~min}$. With a contact time of $15 \mathrm{~s}$ and a time cycle of $40 \mathrm{~s}$ and a Harvard kymograph (Harvard Apparatus Ltd, Kent, UK)

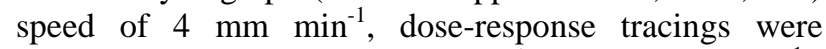
obtained for Acetylcholine $\left(5 \times 10^{-5}-6.4 \times 10^{-3} \mathrm{mg} \mathrm{ml}^{-1}\right)$, Nicotine $\left(5 \times 10^{-2}-6.4 \mathrm{mg} \mathrm{ml}^{-1}\right)$ and EAS $\left(5 \times 10^{-1}-32\right.$

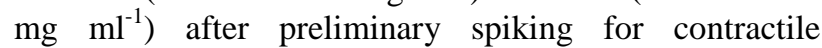
response (histamine did not show contractile activity). The tracings obtained were measured and log doseresponse curves made.

\section{Effect of EAS on the Isolated Rabbit Jejunum}

A New Zealand White rabbit obtained from the Departmental Animal house was sacrificed and the jejunum isolated as earlier described by Okpako and Taiwo (1984). ${ }^{20}$ The abdomen was opened and a length of jejunum is removed and preserved in aerated RingerLocke solution at room temperature. Pieces (about $2 \mathrm{~cm}$ long) were carefully prepared, without stretching or otherwise damaging the tissue. A piece of the jejunum was mounted in $20 \mathrm{ml}$ Ringer Locke's solution maintained at $37^{\circ} \mathrm{C}$ in a Harvard tissue bath. The tissue was constant aerated and made to stabilize for about 15 minutes. Responses of the jejunum to Acetylcholine (2.0 $\mathrm{x} 10^{-4}$ ug $\left.\mathrm{ml}^{-1}\right)$, Adrenaline $\left(1 \mathrm{x} \quad 10^{-3} \mathrm{mg} \mathrm{ml}^{-1}\right)$, Noradrenaline $\left(1 \times 10^{-3} \mathrm{mg} \mathrm{ml}^{-1}\right)$, and EAS (1.4 $\left.\mathrm{mg} \mathrm{ml}^{-1}\right)$ to ascertain agonistic activity (contraction or relaxation) were sought for. With a contact time of $15 \mathrm{~s}$ and a time cycle of $40 \mathrm{~s}$ and a Harvard kymograph speed of $4 \mathrm{~mm}$ $\min ^{-1}$, dose-response tracings were obtained.

\section{Determination of the Site of Action of EAS}

A guinea-pig obtained from the Departmental Animal house was sacrificed. The abdomen was opened and the ileum was taken from the ileo-caecal valve of the small intestine as earlier described by Okpako and Taiwo (1984). ${ }^{20}$ Small strips of about $3 \mathrm{~cm}$ long were cut and kept in Tyrode solution appropriately aerated. A piece of the ileum (about $2 \mathrm{~cm}$ long) mounted in $20 \mathrm{ml}$ Tyrode solution maintained at $37^{\circ} \mathrm{C}$ in a Harvard tissue bath. The tissue was constantly aerated and made to stabilize for about $15 \mathrm{~min}$. With a contact time of $30 \mathrm{~s}$ and a time cycle of 1 min a complete, and a kymograph speed of 4 $\mathrm{mm} \min ^{-1}$, dose-response tracing was generated for Acetylcholine $\left(2 \times 10^{-3}-5.12 \times 10^{-1} \mu \mathrm{g} \mathrm{ml}^{-1}\right)$, after which a sub-maximal response (about $75 \%$ of the maximum response) given by a dose of $6.4 \times 10^{-2} \mu \mathrm{g} \mathrm{ml}^{-1}$, was selected. Equipotent doses (doses that gave similar responses to the submaximal response selected for Acetylcholine) of Nicotine $\left(\begin{array}{lllll}1.0 & \mathrm{x} & 10^{-1} & \mu \mathrm{g} & \mathrm{ml}^{-1}\end{array}\right)$, Histamine $\left(1.1 \times 10^{-1} \mu \mathrm{g} \mathrm{ml}^{-1}\right)$, and $\operatorname{EAS}\left(2.8 \mathrm{mg} \mathrm{ml}^{-1}\right)$ were obtained and responses matched.

Hexamethonium $\left(4.5 \times 10^{-2} \mathrm{mg} \mathrm{ml}^{-1}\right)$ was added to the organ bath and left in contact with the tissue for $30 \mathrm{~s}$ after which the equipotent dose of Nicotine was added to the bath and allowed to act for $30 \mathrm{~s}$ to obtain a response. The tissue was then washed free of the drugs. The step was repeated for Hexamethonium and the matched dose of EAS. The procedures were performed for Atropine $(3.0 \times$

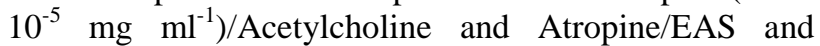
Mepyramine $\left(\begin{array}{lllll}1.6 & \mathrm{x} & 10^{-1} & \mathrm{mg} & \mathrm{ml}^{-1}\end{array}\right)$ /Histamine and Mepyramine/EAS.

\section{Acute and Delayed Toxicity study}

Sprague-Dawley rats were assigned to six treatment groups with five animals per group. EAS was administered at doses of 80,160, 240, 400 and $800 \mathrm{mg}$ $\mathrm{kg}^{-1}$ (representing 1, 2, 3, 5, and 10 times the daily dose as used by the herbalist), per os as a single dose. The control group was given $2 \mathrm{ml} \mathrm{kg}^{-1}$ distilled water per os. Observation for clinical and behavioral symptoms of toxicity and mortality were made hourly for $24 \mathrm{~h}$ and then daily for 14 days. The time of onset, intensity, and duration of these symptoms, if any, was recorded. 
Table 1: Phytochemical constituents of the hydro-ethanolic whole plant extract of Amaranthus spinosus (EAS).

\begin{tabular}{|ll|}
\hline Test & EAS \\
\hline Flavonoids & - \\
\hline Phytosterols & + \\
\hline Alkaloids & + \\
\hline General test for glycosides & + \\
\hline Saponin glycosides & + \\
\hline Tannins & + \\
\hline Anthracene glycosides & - \\
\hline Cyanogenetic glycosides & - \\
\hline Terpenoids & - \\
\hline
\end{tabular}

+ : present, $\quad-:$ absent

\section{Sub-Acute Toxicity Study}

Sprague-Dawley rats were assigned to three treatment groups with five animals per group and housed in metabolic cages (Ugo Basile Biological Research Equipment, Comerio,Va., Italy). EAS was administered at doses of 160 and $240 \mathrm{mg} \mathrm{kg}^{-1}$ (representing 2 and 3 times the daily dose as used by the herbalist), per os for 14 days. Dosing was once daily at a volume of $10 \mathrm{ml} \mathrm{kg}^{-1}$ body weight. Individual dose volumes were calculated based on the animal's most recent recorded body weight. The oral route of administration was used because it is the intended human exposure route. The control group was given distilled water $\left(2 \mathrm{ml} \mathrm{kg}^{-1}\right.$ p.o $)$. A quantitative biochemical test using H11-MA reagent strips for urinalysis (Durui, The Hague, Netherlands) was performed on fresh urine samples obtained before treatment, $24 \mathrm{~h}$ after treatment, and 14 days posttreatment); the color, appearance and smell of the urine samples were also noted (Table 2). Blood samples from the control and treated rats (before treatment, $24 \mathrm{~h}$ after treatment, and 14 days post-treatment) were collected into MediPlus K3 EDTA tubes (Sunphoria Co. Ltd., Taiwan) for hematological assessment (Table 3) using the BC-3000 Plus Auto hematology Analyzer (Mindray, Shenzhen, China).

Table 2: Results on urinalysis performed on sample obtained from Sprague-Dawley rat before treatment, and $24 \mathrm{~h}$ and 14 days after treatment with 160 and $240 \mathrm{mg} / \mathrm{kg}$ of EAS using distilled water as the control, in a sub-acute toxicity study.

\begin{tabular}{|c|c|c|c|c|c|c|c|}
\hline \multirow[t]{2}{*}{ Parameters } & \multirow[t]{2}{*}{ Control } & \multicolumn{2}{|l|}{$2 \mathrm{ml} \mathrm{kg}^{-1} \mathrm{DS}$} & \multicolumn{2}{|c|}{$160 \mathrm{mg} \mathrm{kg}^{-1} \mathrm{EAS}$} & \multicolumn{2}{|c|}{$240 \mathrm{mg} \mathrm{kg}^{-1}$ EAS } \\
\hline & & $24 \mathrm{~h}$ & 14 days & $24 \mathrm{~h}$ & 14 days & $24 \mathrm{~h}$ & 14 days \\
\hline $\begin{array}{l}\text { UBG } \\
\text { (umol/uL) }\end{array}$ & $3.40 \pm 0.00$ & $3.40 \pm 0.00$ & $3.40 \pm 0.00$ & $3.4 \pm 0.00$ & $3.4 \pm 0.00$ & $3.4 \pm 0.00$ & $3.4 \pm 0.00$ \\
\hline BIL (umol/L) & - & - & - & - & - & - & - \\
\hline KET & - & - & - & - & - & - & - \\
\hline BLD (Ery/uL) & - & - & - & - & - & - & - \\
\hline PROT (g/L) & - & - & - & - & - & - & - \\
\hline NIT & - & - & - & - & - & - & - \\
\hline LEU & - & - & - & - & - & - & - \\
\hline GLU(mmol/L) & - & - & - & - & - & - & - \\
\hline SG & $\begin{array}{l}1.025 \pm \\
0.00\end{array}$ & $\begin{array}{l}1.025 \pm \\
0.00\end{array}$ & $\begin{array}{l}1.025 \pm \\
0.00\end{array}$ & $\begin{array}{l}1.02 \pm \\
0.01\end{array}$ & $\begin{array}{l}1.025 \pm \\
0.00\end{array}$ & $\begin{array}{l}1.025 \pm \\
0.01\end{array}$ & $\begin{array}{l}1.02 \pm \\
0.76\end{array}$ \\
\hline $\mathrm{pH}$ & $6.17 \pm 0.58$ & $\begin{array}{l}6.00 \pm \\
0.350\end{array}$ & $6.00 \pm 0.00$ & $\begin{array}{l}6.17 \pm \\
0.58\end{array}$ & $6.5 \pm 0.00$ & $6.17 \pm 0.29$ & $\begin{array}{l}6.00 \pm \\
0.00\end{array}$ \\
\hline $\operatorname{MALB}(\mathrm{g} / \mathrm{L})$ & $(-)$ & - & - & - & - & - & - \\
\hline
\end{tabular}

Values are means $\pm \mathrm{SD}, \mathrm{n}=5$. Values obtained for the various parameters during treatments were not significantly different from the control (One-way ANOVA followed by Dunnet's test post hoc). Distilled water (DS), Urobilinogen (UBG); Bilirubin(BIL);

Ketones(KET); Blood(BLD); Protein(PROT); Nitrite(NIT); leucocytes(LEU); Glucose (GLU); Specific gravity(SG); Microalbumin (MALB). 
Table 3: Results on hematological assessment performed on blood sample obtained from Sprague-Dawley rat before, and after treatment with 160 and $240 \mathrm{mg} \mathrm{kg}^{-1}$ of EAS, using distilled water as the control, in a sub-acute toxicity study.

\begin{tabular}{|c|c|c|c|c|c|c|c|}
\hline & \multirow{2}{*}{ Control } & \multicolumn{2}{|c|}{$2 \mathrm{ml} \mathrm{kg}^{-1} \mathrm{DS}$} & \multicolumn{2}{|c|}{$160 \mathrm{mg} \mathrm{kg}^{-1}$ EAS } & \multicolumn{2}{|c|}{$240 \mathrm{mg} \mathrm{kg}^{-1} \mathrm{EAS}$} \\
\hline & & $24 \mathrm{~h}$ & 14 days & $24 \mathrm{~h}$ & 14 days & $24 \mathrm{~h}$ & 14 days \\
\hline $\begin{array}{l}\text { WBC } \\
\left(\times 10^{3} / \mathrm{L}\right)\end{array}$ & $\begin{array}{l}5.63 \pm \\
0.85\end{array}$ & $\begin{array}{l}6.16 \pm \\
0.71\end{array}$ & $\begin{array}{l}5.71 \pm \\
0.69\end{array}$ & $\begin{array}{l}6.35 \pm \\
0.57\end{array}$ & $\begin{array}{l}5.94 \pm \\
0.71\end{array}$ & $\begin{array}{l}5.58 \pm \\
1.11\end{array}$ & $\begin{array}{c}5.93 \pm \\
0.83\end{array}$ \\
\hline HGB (g/dl) & $\begin{array}{l}15.12 \pm \\
1.00\end{array}$ & $\begin{array}{l}15.08 \pm \\
1.22\end{array}$ & $\begin{array}{l}15.16 \pm \\
0.78\end{array}$ & $\begin{array}{l}15.22 \pm \\
0.68\end{array}$ & $\begin{array}{l}14.88 \pm \\
1.03\end{array}$ & $\begin{array}{l}15.46 \pm \\
1.27\end{array}$ & $\begin{array}{l}15.30 \pm \\
0.84\end{array}$ \\
\hline $\mathrm{RBC}\left(\mathrm{x} 10^{6} / \mathrm{L}\right)$ & $\begin{array}{l}7.10 \pm \\
0.54\end{array}$ & $\begin{array}{l}7.06 \pm \\
0.89\end{array}$ & $\begin{array}{l}7.14 \pm \\
0.56\end{array}$ & $\begin{array}{l}7.17 \pm \\
0.78\end{array}$ & $\begin{array}{l}7.03 \pm \\
0.92\end{array}$ & $\begin{array}{l}7.21 \pm \\
0.67\end{array}$ & $\begin{array}{l}7.15 \pm \\
0.79\end{array}$ \\
\hline $\mathrm{HCT}(\%)$ & $\begin{array}{l}46.25 \pm \\
3.63\end{array}$ & $\begin{array}{l}48.68 \pm \\
3.61\end{array}$ & $\begin{array}{l}46.17 \pm \\
4.23\end{array}$ & $\begin{array}{l}45.26 \pm \\
5.18\end{array}$ & $\begin{array}{l}47.90 \pm \\
3.02\end{array}$ & $\begin{array}{l}45.8 \pm \\
6.39\end{array}$ & $\begin{array}{l}46.33 \pm \\
4.25\end{array}$ \\
\hline MCV (fL) & $\begin{array}{l}82.7 \pm \\
9.43\end{array}$ & $\begin{array}{l}84.23 \pm \\
7.54\end{array}$ & $\begin{array}{l}81.83 \pm \\
9.16\end{array}$ & $\begin{array}{l}82.30 \pm \\
5.88\end{array}$ & $\begin{array}{l}89.01 \pm \\
6.94\end{array}$ & $\begin{array}{l}80.4 \pm \\
8.46\end{array}$ & $\begin{array}{l}81.53 \pm \\
6.80\end{array}$ \\
\hline $\mathrm{MCH}(\mathrm{pg})$ & $\begin{array}{l}22.1 \pm \\
2.36\end{array}$ & $\begin{array}{l}21.93 \pm \\
1.35\end{array}$ & $\begin{array}{l}23.11 \pm \\
1.22\end{array}$ & $\begin{array}{l}21.23 \pm \\
2.01\end{array}$ & $\begin{array}{l}20.83 \pm \\
2.01\end{array}$ & $\begin{array}{l}21.34 \pm \\
1.38\end{array}$ & $\begin{array}{l}21.12 \pm \\
1.22\end{array}$ \\
\hline $\mathrm{MCHC}(\mathrm{g} / \mathrm{dl})$ & $\begin{array}{l}25.73 \pm \\
1.05\end{array}$ & $\begin{array}{l}25.05 \pm \\
0.93\end{array}$ & $\begin{array}{l}26.45 \pm \\
0.88\end{array}$ & $\begin{array}{l}27.02 \pm \\
0.60\end{array}$ & $\begin{array}{l}24.83 \pm \\
1.22\end{array}$ & $\begin{array}{l}24.93 \pm \\
1.38\end{array}$ & $\begin{array}{l}25.12 \pm \\
0.72\end{array}$ \\
\hline RDW-CV (\%) & $\begin{array}{l}11.7 \pm \\
0.63\end{array}$ & $\begin{array}{l}11.32 \pm \\
0.88\end{array}$ & $\begin{array}{l}12.1 \pm \\
0.75\end{array}$ & $\begin{array}{l}11.4 \pm \\
1.25\end{array}$ & $\begin{array}{l}12.20 \pm \\
1.32\end{array}$ & $\begin{array}{l}11.9 \pm \\
0.75\end{array}$ & $\begin{array}{l}12.01 \pm \\
1.11\end{array}$ \\
\hline RDW-SD (fL) & $\begin{array}{l}28.97 \pm \\
0.88\end{array}$ & $\begin{array}{l}28.33 \pm \\
0.65\end{array}$ & $\begin{array}{l}29.43 \pm \\
0.56\end{array}$ & $\begin{array}{l}27.93 \pm \\
0.76\end{array}$ & $\begin{array}{l}29.02 \pm \\
0.55\end{array}$ & $\begin{array}{l}28.24 \pm \\
1.22\end{array}$ & $\begin{array}{l}27.63 \pm \\
0.61\end{array}$ \\
\hline $\operatorname{PLT}\left(\times 10^{5} / \mathrm{L}\right)$ & $\begin{array}{l}7.76 \pm \\
1.3\end{array}$ & $\begin{array}{l}8.4 \pm \\
1.8\end{array}$ & $\begin{array}{l}7.3 \pm \\
2.1\end{array}$ & $\begin{array}{l}8.43 \pm \\
1.98\end{array}$ & $\begin{array}{l}7.29 \pm \\
1.7\end{array}$ & $\begin{array}{l}9.13 \pm \\
2.44\end{array}$ & $\begin{array}{l}7.66 \pm \\
1.64\end{array}$ \\
\hline MPV (fL) & $\begin{array}{l}6.64 \pm \\
0.54\end{array}$ & $\begin{array}{l}6.36 \pm \\
0.62\end{array}$ & $\begin{array}{l}6.56 \pm \\
0.48\end{array}$ & $\begin{array}{c}6.36 \pm \\
0.41\end{array}$ & $\begin{array}{l}6.20 \pm \\
0.39\end{array}$ & $\begin{array}{l}6.55 \pm \\
0.95\end{array}$ & $\begin{array}{l}6.62 \pm \\
0.84\end{array}$ \\
\hline PDW & $\begin{array}{l}6.86 \pm \\
0.32\end{array}$ & $\begin{array}{l}6.64 \pm \\
0.25\end{array}$ & $\begin{array}{l}7.07 \pm \\
0.52\end{array}$ & $\begin{array}{l}6.86 \pm \\
0.48\end{array}$ & $\begin{array}{l}7.17 \pm \\
0.37\end{array}$ & $\begin{array}{l}7.06 \pm \\
0.55\end{array}$ & $\begin{array}{l}6.68 \pm \\
0.78\end{array}$ \\
\hline P_LCR (\%) & $\begin{array}{l}4.71 \pm \\
0.85\end{array}$ & $\begin{array}{l}5.02 \pm \\
0.64\end{array}$ & $\begin{array}{l}4.64 \pm \\
0.53\end{array}$ & $\begin{array}{l}4.88 \pm \\
0.86\end{array}$ & $\begin{array}{l}5.17 \pm \\
0.84\end{array}$ & $\begin{array}{l}5.33 \pm \\
1.01\end{array}$ & $\begin{array}{l}4.67 \pm \\
0.78\end{array}$ \\
\hline
\end{tabular}

Values are means SD, $\mathrm{n}=5$. Values obtained for the various parameters before treatment, and $24 \mathrm{~h}$ and 14 days post-treatment were not significantly different compared to the control (One-way ANOVA followed by Dunnet's test post hoc). White Blood Cells (WBC), Hemoglobin (HGB), Red Blood Cells (RBC), Hematocrit (HCT), Mean Corpuscular Volume (MCV), Mean Corpuscular Hemoglobin (MCH), Mean Corpuscular Hemoglobin Concentration (MCHC), Red Blood Cell Distribution Width (RDW-CV \& RWD-SD), Platelet Count (PLT), Mean Platelet Volume (MPV), Platelet Distribution Width (PDW), Platelet Larger Cell Ratio (P-LCR).

During the 14-day period, physical (In-life) observation was made. Cages were checked daily for mortality. Liver and kidney function tests (Tables 4 and 5) was performed on plasma obtained from coagulated blood taken prior to and after 14 days of treatment using the Flexor Junior clinical chemical analyzer (Vital Scientific B.V, The Netherlands) at the KNUST Hospital, Kumasi, Ghana.

\section{Data Analysis}

Means, standard deviations, graphs and statistical evaluations were done using GraphPad Prism (GraphPad Software, San Diego, CA, USA). Significant differences between percentage inhibitions were determined (compared to zero inhibition) using One-Way Analysis of Variance followed by Dunnett's Multiple Comparisons
Test post hoc. $\mathrm{P} \leq 0.05$ was considered statistically significant.

\section{RESULTS}

\section{Phytochemical Screening}

EAS was found to contain, phytosterols, alkaloids, saponins, glycosides, and tannins as shown in Table 1.

\section{TLC Analysis}

The TLC chromatogram developed using chloroform: methanol in the ratio 93:7 showed four spots with the $R_{f}$ values of $0.18,0.30,0.36$ and 0.46 . 
Table 4: Liver function test results obtained from Sprague-Dawley rat prior to, and after treatment with 160 and $240 \mathrm{mg} / \mathrm{kg}$ of EAS for 14 days using distilled water as the control, in a sub-acute toxicity study.

\begin{tabular}{|lllll|}
\hline & Control & $2 \mathbf{~ m l ~ k g}{ }^{-1} \mathrm{DS}$ & $\mathbf{1 6 0} \mathrm{mg} \mathrm{kg}^{-1} \mathrm{EAS}$ & $\mathbf{2 4 0} \mathbf{~ m g ~ k g}^{-1}$ EAS \\
\hline AST/GOT $(\mathrm{U} / \mathrm{I})$ & $10.85 \pm 6.80$ & $12.22 \pm 7.07$ & $10.65 \pm 8.22$ & $11.59 \pm 8.35$ \\
\hline ALT/GPT $(\mathrm{U} / \mathrm{I})$ & $7.81 \pm 5.23$ & $9.44 \pm 4.58$ & $8.67 \pm 4.96$ & $8.42 \pm 5.45$ \\
\hline GGT $(\mu \mathrm{mol} / \mathrm{l})$ & $5.34 \pm 4.28$ & $6.82 \pm 4.48$ & $5.82 \pm 3.86$ & $5.80 \pm 3.63$ \\
\hline ALP $(\mathrm{U} / \mathrm{I})$ & $14.24 \pm 8.10$ & $14.53 \pm 4.60$ & $13.72 \pm 5.34$ & $13.62 \pm 8.21$ \\
\hline Total protein $(\mathrm{g} / \mathrm{l})$ & $58.93 \pm 14.87$ & $54.94 \pm 18.56$ & $49.98 \pm 16.38$ & $65.12 \pm 12.62$ \\
\hline Albumin $(\mathrm{g} / \mathrm{l})$ & $22.94 \pm 16.79$ & $23.59 \pm 10.35$ & $30.37 \pm 8.41$ & $25.66 \pm 13.86$ \\
\hline Bil. Direct $(\mu \mathrm{mol} / \mathrm{l})$ & $1.82 \pm 0.12$ & $1.94 \pm 0.15$ & $1.85 \pm 0.12$ & $1.90 \pm 0.20$ \\
\hline Bil Indirect $(\mu \mathrm{mol} / \mathrm{l})$ & $0.71 \pm 0.26$ & $0.69 \pm 0.21$ & $0.73 \pm 0.12$ & $0.75 \pm 0.14$ \\
\hline TBil $(\mu \mathrm{mol} / \mathrm{l})$ & $2.53 \pm 0.23$ & $2.63 \pm 0.19$ & $2.58 \pm 0.18$ & $2.65 \pm 0.24$ \\
\hline
\end{tabular}

Values are Means $\pm \mathrm{SD}, \mathrm{N}=5$. Values obtained after EAS treatment were not significantly different from that of the control (One-Way Analysis of Variance followed by Dunnet's post-hoc test). DS= Distilled water, ALT/GPT = Alanine Transaminase/Glutamic Pyruvate Transaminase, AST/GOT = Aspartate transaminase/Glutamic Oxaloacetic transaminase, ALP = Alkaline Phosphatase, GGT = Gamma Glutamyl Transferase . Bil= Bilirubin; TBIL= Total bilirubin

Table 5: Plasma urea and creatinine concentrations obtained after kidney function tests performed on blood sample obtained from Sprague-Dawley rat prior to, and after treatment with 160 and $240 \mathrm{mg} \mathrm{kg}^{-1}$ of EAS for 14 days using distilled water (DS) as the control.

\begin{tabular}{|lllll|}
\hline & Control & $\mathbf{2 ~} \mathbf{~ m ~ k g}^{-1} \mathbf{D S}$ & $\mathbf{1 6 0} \mathbf{~ m g ~ k g}^{-1}$ EAS & $\mathbf{2 4 0} \mathbf{~ m g ~ k g ~}^{-1}$ EAS \\
\hline Urea $(\mathrm{mmol} / \mathrm{l})$ & $31.28 \pm 19.46$ & $33.72 \pm 14.88$ & $29.92 \pm 13.65$ & $3648 \pm 16.72$ \\
\hline Creatinine $(\mu \mathrm{mol} / \mathrm{l})$ & $0.49 \pm 0.45$ & $0.60 \pm 0.57$ & $0.45 \pm 0.42$ & $0.58 \pm 0.36$ \\
\hline
\end{tabular}

Values are Means $\pm \mathrm{SD}, \mathrm{N}=5$. Plasma urea and creatinine obtained after EAS treatment were not significantly different from that of the control (One-Way Analysis of Variance followed by Dunnet's post-hoc test).

\section{HPLC Analysis}

The HPLC chromatogram showed two peaks when the detector was set to $254 \mathrm{~nm}$ (Figure 2).

\section{Isolated Rat Bladder Preparation}

Preliminary investigations showed that Acetylcholine, Nicotine, and EAS caused contractile responses in the rat bladder whiles histamine showed no significant response (Figure 3).

\section{Isolated Rabbit Jejunum}

EAS on the rabbit jejunum showed contractions similar to Acetylcholine with no relaxation effects as Adrenaline or Noradrenaline established (Figure 4).

\section{Determination of Site of Action}

Acetylcholine, Nicotine, Histamine and EAS showed contractions of the guinea-pig ileum. The response by EAS was blocked by hexamethonium $(77.50 \pm 8.50 \% ; P$ $\leq 0.001)$, mepyramine $(49.2 \pm 6.80 \% ; P \leq 0.001)$, and atropine $(22.45 \pm 5.22 \% ; P \leq 0.01)$ (Figure 5).

\section{Acute Toxicity Study}

There was on hair loss, open or closed lesions, or abnormal masses on skin. No secretions and excretions from the eye, nose, oral cavity, anus, and external genitalia were observed. There was no change in pupil size and respiratory pattern and no "chattering" was heard. Changes in gait and posture, clonic or tonic movements, stereotypy (e.g., excessive grooming, repetitive circling) or bizarre behavior (e.g., selfmutilation, walking backward) were not observed. Lethargy, aggression and hunch appearance was also not noted. Pharmacological toxic symptoms such as; constipation, hemorrhage, sedation, diarrhoea, polyuria, 
polydipsia, polyphagia, anorexia, loss of autonomic reflexes, decreased locomotory activity, neuromuscular inco-ordination and collapse, hyperesthesia, hypothermia, twitching, spasticity, writhing, and convulsion were not present. No mortality occurred during the study.

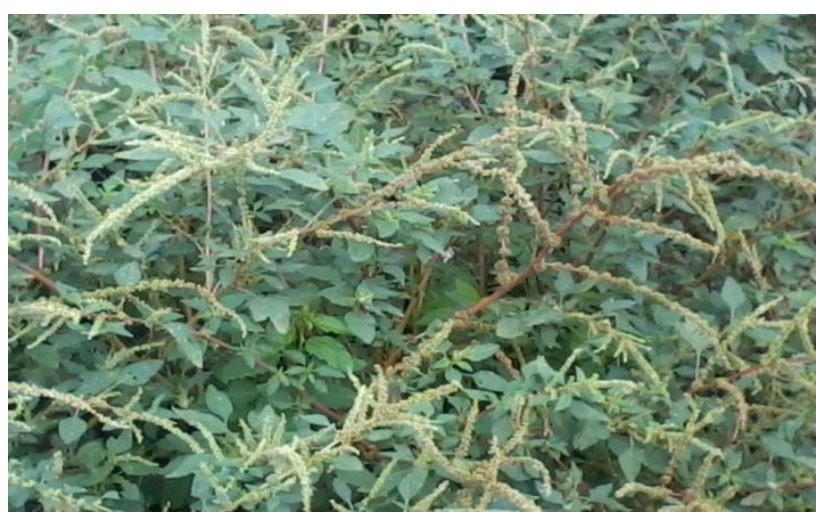

Figure 1: Amaranthus spinosus. Picture taken around Ayeduase, Kumasi, Ghana.

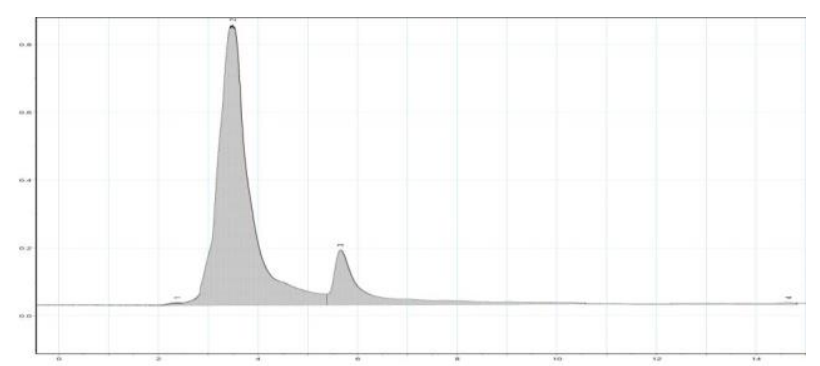

Figure 2: HPLC analysis of EAS. Stationary phase phenyl column; Mobile phase - methanol: water (50:50). UV detection was at $254 \mathrm{~nm}$.

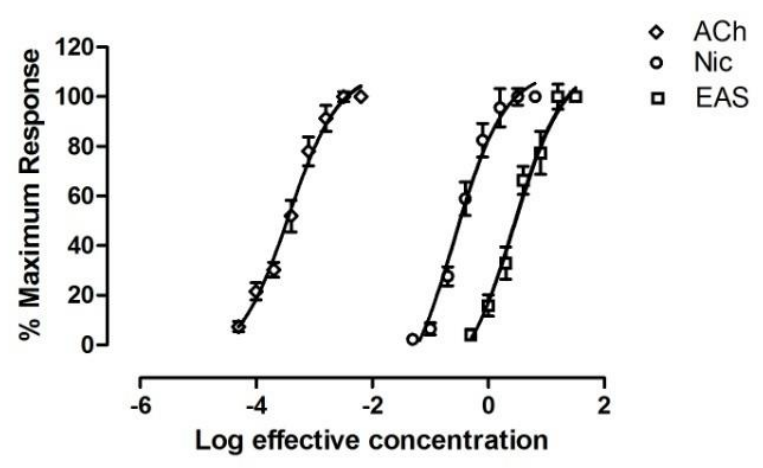

Figure 3: Log concentration-response curve for Acetylcholine (Ach), Nicotine (Nic), and the hydroethanolic extract of Amaranthus spinosus (EAS) and on the rat bladder.

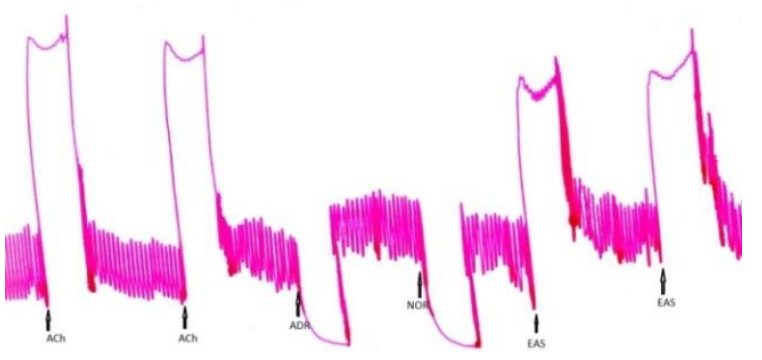

Figure 4: Contractile and relaxation responses showed by Acetylcholine (ACh), Adrenaline (ADR),

Noradrenaline (NOR), and hydro-ethanolic whole plant extract of Amaranthus spinosus (EAS).

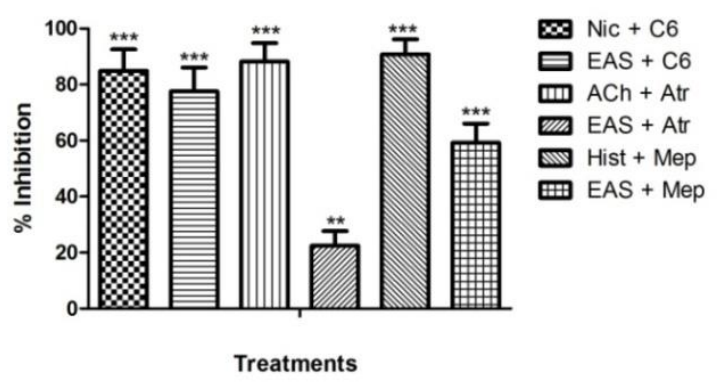

Figure 5: Percentage inhibition of Nicotine (Nic), Acetylcholine (Ach), Histamine (Hist) and EAS by

Hexamethonium (C6), Atropine (Atr), and Mepyramine (Mep).

Values plotted are means SD, N=3. Significant differences between percentage inhibitions were determined (compared to zero inhibition) using One-Way Analysis of Variance followed by Dunnett's Multiple Comparisons Test post hoc. ** implies $\mathrm{P} \leq 0.01 ; * * *$ implies $\mathrm{P} \leq 0.001$.

\section{Sub-Acute Toxicity Study}

There were no significant changes in the urine profile (Table 2). All urine samples were straw coloured and clear with normal rat urine odour. Changes in hematological profile between control and treated rats were not significant (Table 3). All parameter measured were within normal range (with respect to the control) after performing liver function tests (Table 4). Urea and creatinine levels (with the kidney function test) did not vary significantly from that of normal rats (Table 5).

\section{DISCUSSION}

EAS caused contraction of the isolated rat bladder in a similar fashion as Acetylcholine and Nicotine. Contraction of the bladder causes voiding of urine from the urinary bladder. The bladder receives both parasympathetic and sympathetic innervations. ${ }^{21}$ Studies have shown that in human and experimental animals the 
ability of bladder to contract is reliant on acetylcholine. ${ }^{22}$ The muscular coat of the body of the rat bladder is innervated almost completely by cholinergic endings: adrenergic endings are uncommon. ${ }^{23}$ Fetscher C. et al., $(2002)^{24}$ found that M3 receptors are the most significant mediators of bladder contraction.

In nearly all animal species, detrusor smooth muscle has been found to contain muscarinic receptors of the M2 and M3 subtypes. ${ }^{25}$ The most imperative of these receptors in contraction of the detrusor muscle of the bladder have been established to be the M3 receptor subtype. ${ }^{26}$ Activation of these M3 receptors directly by acetylcholine on the detrusor muscle causes contractions of the rat bladder. Stimulation of the M2 receptors indirectly aid in voiding by reversal of the relaxation caused by $\beta$-adrenoceptor agonists. This suggests that the contractile activity observed with the extract on the bladder could be cholinergic receptor mediated.

Although studies have also shown that alpha adrenoceptors (are the predominant adrenoceptors in the bladder neck compared to beta adrenoceptors) are also involved in contractile response of the bladder, their effect is not very significant. ${ }^{27}$ Beta adrenoceptors are also found to be predominant in the detrusor muscle compared to alpha adrenoceptors and are involved in bladder relaxation. ${ }^{27}$ Our preliminary investigation of the effect of EAS on the rabbit jejunum suggested that the extract had no significant and observable adrenoceptor activity and hence could not have cause contraction of the bladder and voiding of urine via adrenergic mechanisms. The extract will not be causing relaxation of the bladder either; as it did not cause relaxation of the rabbit jejunum as seen with adrenaline or noradrenaline.

Effects of Acetylcholine, Nicotine, Histamine, and EAS and antagonism on the guinea-pig ileum revealed that activity of EAS could be mediated by nicotinic receptor as extent of inhibition of Nicotine by Hexamethonium was comparable to EAS inhibition by Hexamethonium. Studies by Kizawa et al., (1988) ${ }^{28}$ on a different the rabbit bladder suggests nicotine causing contraction on the bladder which was blocked by hexamethonium, atropine and capsaicin. This gives the indication that contractile responses on the bladder by nicotine may involve nicotine-induced responses and partly due to acetylcholine and tachykinnin release. Ganglion stimulation of nicotinic receptors by nicotine or nicotinic receptor stimulants cause the release of acetylcholine at the neuroeffector junction which binds to muscarinic receptors to elicit a response. ${ }^{29}$

The antagonism also revealed significant histaminic receptor activity. This may also contribute to its contractile activity of the bladder and its ischuretic effect. Anderrson $(1993)^{26}$ indicated that histamine causes contraction of smooth muscles. This is also stipulated by Hill, 1990 that histamine activates $\mathrm{H} 1$ receptors in smooth muscle to release $\mathrm{Ca}^{2+}$ from intracellular stores of smooth muscles including the urinary bladder. ${ }^{30}$ EAS was less significantly inhibited by atropine suggesting a mild muscarinic effect. This effect may however contribute immensely to the contractions of the bladder observed for the extract. Acetylcholine in the bladder has muscarinic effects and may thus act on muscarinic receptors which are predominant on the bladder wall. Any drug with muscarinic activity will therefore act same. Thus EAS acting via nicotinic, histaminic and muscarinic receptors makes it a potent ischuretic drug and therefore a very effective drug in managing urinary retention.

Phytochemical screening revealed the presence of phytosterols, glycosides, and tannins among others. Phytosterols, in two randomized, placebo-controlled, clinical studies improved urinary flow rate and alleviated symptoms of benign prostatic hyperplasia. ${ }^{30} \mathrm{~A}$ herbal capsule for the treatment of benign prostatic hyperplasia, Harzol, which contains $\beta$-sitosterol and other phytosterols, has been used in Germany since $1977 .^{31}$ Thus the presence of phytosterols may in part be responsible for the ischuretic activity of EAS. Glycosides in Digitalis increase the intravesical pressure and decreases bladder capacity. ${ }^{32}$ Mediation of this effect is mainly by increasing the tension of the bladder wall. Based on the presence of glycosides in the extract, they may have an effect on bladder contraction by neurogenic innervation leading to the secretion of acetylcholine and other neuromodulators including vasoactive polypeptide (VIP), neuropeptide Y (NYP). These control local blood flow to the bladder and the release of acetylcholine required for contraction of the bladder. Tannins present in the extract may be of importance in the management of urinary retention involving benign prostatic hyperplasia. This speculation is based on reported biological effects of tannins as anti-inflammatory and anti-cancer agents achieved by decreasing cell cycle progression. ${ }^{33}$

The HPLC chromatogram showed two peaks implying the presence of two main compounds or group of compounds with absorption at $254 \mathrm{~nm}$. Compounds with the benzenoid aromatic ring are usually responsible for absorption at that wavelength. The above chromatogram may serve as a fingerprint reference for extract obtained under the same conditions. Also peak A was very pronounce and represents the more polar component(s) of the extract. If found to be unicompononent, that compound may be used as a biomarker in the standardization of the extract.

\section{Acute Toxicity Study}

It can be inferred from the acute toxicity study that the extract is not lethal at doses up to $800 \mathrm{mg} \mathrm{kg}^{-1}$ since no deaths occurred. It did not cause allergic reactions and cutaneous neurogenic inflammation, resulting in pruritus, ${ }^{34}$ which rats usually respond to by scratching, licking, or biting; hence making them look unkempt. Secretions and excretions from the eye, nose, oral cavity, bladder, anus (SLUDGEM), as well as miosis, respiration distress; which would have indicated muscarinic/nicotinic 
receptor overactivity, ${ }^{35}$ did not happen. No excitation, or increased activity was observed indication that the extract did not have cause autonomic nervous system hyperactivity in experimental animals. Extract-related CNS depressant and muscle relaxant effect which would have be noticed as sedation, lethargy, decreased locomotor activity ${ }^{36}$ was not observed. None of the pharmacological symptoms sought for were not found. Changes in gait and posture, clonic or tonic movements, stereotypy (e.g., excessive grooming, repetitive circling) or bizarre behavior (e.g., self-mutilation, walking backward) are usually indicators of neuromuscular incoordination or disorder. ${ }^{37}$

\section{Sub-Acute Toxicity Study}

EAS at 160 and $240 \mathrm{mg} \mathrm{kg}^{-1}$ did not change the urine profile significantly indicating that the extract may not had detrimental effects on metabolism, confirmed by results from urinalysis which among other would give information on in-borne errors of metabolism. ${ }^{38}$

Changes in hematological profile could be myeloproliferative $^{39}$ or myelosuppressive disorders. ${ }^{40} \mathrm{~A}$ reduction could be hemolytic disorder. The extract did not cause anemia, or polycythemia, leukocytopenia, or leucocytosis, and or thrombocytopenia, or thrombocytosis, as it did not significantly affect the hematological profile. Normal levels of bilirubin (LFT), and trace quantities of bilirubin and urobilinogen recorded in urinalysis could confirm this finding in the hematological analysis. Liver function tests (LFTs), are groups of clinical biochemistry laboratory blood assays designed to give information about the state of a patient's liver. ${ }^{41}$ Considering results obtained for LFTs the extract did not cause injury/damage to hepatocytes as was evidently seen by the insignificant differences in ALT and $\mathrm{AST}^{42}$ in the treated rats compared to the normal and therefore does not affect the functionality of the liver. It also does not cause a decrease in the liver's excretory function evidently seen by normal ALP and GGT and total bilirubin. ${ }^{43}$ This does not also affect the synthetic function of the liver. Albumin, globulin and total protein levels in LFTs give information on the synthetic function of the liver. ${ }^{43}$

Urea and creatinine levels recorded over the entire study period were not significantly different. This gives an indication that the kidney's function was not affected by the treatment. Elevated creatinine (and sometimes urea) however, warn of possible malfunction of the kidneys.

\section{CONCLUSION}

The hydro-ethanolic extract of Amaranthus spinosus has ischuretic activity possibly mediated via nicotinic, histaminic and muscarinic receptor stimulation and is safe to use in ischuria.

\section{ACKNOWLEDGEMENTS}

Authors would like to thank Madam Mary Margaret Darkwah Panyin and Madam Mary Margaret Darkwah Kakra CEOs, Twin PK Herbal Centre, Kumasi, Ghana, for providing information on the traditional use of the plant studied.

\section{Funding: None}

Conflict of interest: None declared

Ethical approval: Approved by the Departmental Ethics Committee

\section{REFERENCES}

1. Gyasi-Sarpong CK, Yenli EMT, Idriss A, Arhiz AA, Aboah K, Azorliade R, et al. Bacterial urinary tract infection among males with lower urinary tract obstruction at Komfo Anokye Teaching Hospital, Kumasi, Ghana. J Urol. 2012;2:131-6.

2. Curtis LA, Dolan TS, Cespedes DR. Acute urinary retention and urinary incontinence. Emerg Med Clin North Am. 2001;19(3):591-620.

3. Glavind $\mathrm{K}$ and Bjork J. Incidence and treatment of urinary retention postpartum. Int Urogynaecol J. 2003;14:119-21.

4. Selius BA and Subedi R. Urinary retention in adults: diagnosis and initial management. Am Fam Physician 2008;77(5):643-50.

5. Kavia RB, Daha SN, Dasgupta R, Elneil S, Fowler CJ. Urinary retention in women: its causes and management. BJU International, 2006;97:281-7.

6. Grosshans U, Passadori Y, Peters B. Urinary retention in the elderly: A study of 100 hospitalized patients. J Am Geriatr Soc. 1993;41:633-8.

7. Kalejaiye $\mathrm{O}$ and Speakman MJ. Management of acute and chronic urinary retention in men. European Urology Supplements 2009;8:523-9.

8. Nickel JC. Urinary retention. National Kidney and Urologic Diseases Information Clearinghouse (NKUDIC). NIH Publication No. 08-6089. 2007. Available at: http://kidney.niddk.nih.gov/kudiseases/ pubs/UrinaryRetention/\#diagnosis. Accessed 21 June 2013.

9. Mshana NR, Abbiw DK, Addae-Mensah I, Adjanohoun E, Ahyi MRA, Ekpere JA, et al. Traditional Medicine and Pharmacopoeia, Contribution to the revision of ethnobotanical and Floristic Studies in Ghana. Lagos, Nigeria: Organization of African Unity (OAU)/ Scientific and Technical Research Commission (STRC); 2000.

10. Burkill HM. The useful plants of West Tropical Africa. 2nd ed. Volume 1, Families A-D. Richmond, United Kingdom, Royal Botanic Gardens, Kew; 1985: 960 pages.

11. Lemmens RHMJ and Bunyapraphatsara N. Amaranthus spinosus L. In: de Padua LS, Bunyapraphatsara N, Lemmens RHMJ, eds. Plant 
Resources of South-East Asia No 12(1). Medicinal and poisonous plants 1. Leiden, Netherlands: Backhuys Publishers;1999:110-13.

12. Zeashan H, Amnesh G, Ras CV, Singh SI. Antinociceptive activity of Amaranthus spinosus in experimental animals. J Ethnopharmacol. 2009; 122(3):492-6.

13. Lin B, Ching B, Lin Y. Amaranthus spinosus water extract stimulating proliferation of B-lymphocytes in vitro. Int Immunopharmacol. 2005;5(4):711-22.

14. Olajide OA, Ogunleye BR, Erinle TO. Antiinflammatory properties of Amaranthus spinosus leaf extract. Pharmaceutical Biology, 2004; 42(7):521-25.

15. Chaundry MA, Imran I, Bashir S, Mehmood MH, Rehmon N, Gilani A. Evaluation of gut modulatory and bronchodilatory activity of Amaranthus spinosus Linn. BMC Complement Altern Med. 2012;12:166.

16. Wagner $\mathrm{H}$. and Bladt S. Plant Drug Analysis: A Thin Layer Chromatography. 2nd ed, Verlag Berlin Heidelberg: Springer; 1996.

17. Harborne JB, Phytochemical Methods: A Guide to Modern Techniques of Plant Analysis, 3rd ed, Springer, London, 1998:302.

18. Kujur RS, Singh V, Ram M, Yadava HN, Singh KK, Kumari S, Roy BK. Antidiabetic activity and phytochemical screening of crude extract of Stevia rebaudiana in alloxan-induced diabetic rats. Pharmacognosy Res. 2010;2(4):258-63.

19. Saito M and Miyagawa I.. Bladder dysfunction after acute urinary retention in rats. $\mathrm{J}$ Urol. 2001;165(5):1745-7.

20. Okpako DT and Taiwo YOO. Cyclo-oxyginase inhibitors antagonize indirectly evoked contractions of the guinea-pig isolated ileum by inhibiting acetylcholine release. Br J Pharm. 1984;82:577-85.

21. Taira N. The autonomic pharmacology of the bladder. Annu Rev Pharmacol. 1972;12:197-208.

22. Boselli C, Govoni S, Condins HM, D’Agostino G. Bladder instability; a re-appraisal of classical and experimental approaches and development of new therapeutic strategies. J Auton Pharmacol. 2001;21(5):219-29.

23. Watanabe $\mathrm{H}$ and Yamamoto TY. Autonomic innervations of the muscles in the wall of the bladder and proximal urethra of male rats. J Anat. 1979;128(4):873-86.

24. Fetscher C, Fleichman M, Schimdt M, Krege S, Michel MC. M3 muscarinic receptors mediate contraction of human urinary bladder. $\mathrm{Br} \quad \mathrm{J}$ Pharmacol. 2002;136:641-4.

25. Chess-Williams R. Muscarinic receptors of the urinary bladder: detrusor, urothelial and prejunctional. Auton. Autacoid Pharmacol. 2002;22:133-45.

26. Andersson KE, Holmquist F, Fovaeus M, Hedlund $\mathrm{H}$, Sundler R. Muscarinic receptor stimulation of phosphoinositide hydrolysis in the human isolated urinary bladder. J Urol., 1991;146:1156-9.

27. Awad SA, Bruce AW, Carro-Ciampi G, Downie JW, Lin M. Distribution of alpha and beta adrenoceptors in human urinary bladder. $\mathrm{Br} \mathrm{J}$ Pharmacol. 1974;50:525-9.

28. Kizawa Y, Takayanagi I, Shinkai M, Ohno Y. Pharmacological action of nicotine in the isolated urinary bladder from rabbit: Special reference to the chronic nicotine treatment. Gen Pharmacol. 1988;19(2):269-71.

29. Vizi ES. Acetylcholine release from guinea-pig ileum by parasympathetic ganglion stimulants and gastrin-like polypeptides. $\mathrm{Br} \mathrm{J}$ Pharmacol 1973;47:765-77.

30. Berges RR, Windeler J, Trampisch TH, Senge TH. Randomized, placebo-controlled, double-blind clinical trial of beta-sitosterol in patients with benign prostatic hypertrophy. Lancet 1995;345:1529-32.

31. Klippel KF, Hiltl DM, Schipp B. A multicentric, placebo-controlled, double-blind clinical trial of beta-sitosterol (phytosterol) for the treatment of benign prostatic hypertrophy. $\mathrm{Br} \mathrm{J}$ Urol. 1997;80:427-32.

32. Sadoughi N, Tandoc V, Ablin RJ, Bush IM. Effects of digitalis on urinary retention. Urology 1973;2(5): 582-3.

33. Marienfeld C, Tadlock L, Yamagiwa Y, Patel Y. Inhibition of cholangiocarcinoma growth by tannic acid. Hepatology 2003;37(5):1097-1104.

34. Steinhoff M, Ständer S, Seeliger S, Ansel JC, Schmelz M, Luger T. Modern aspects of cutaneous neurogenic inflammation, Arch Dermatol., 2003;139(11):1479-88.

35. Ganesan K, Raza SK, Vijayaraghavan R. Chemical warfare agents. J Pharm Bioallied Sci., 2010;2(3):166-78.

36. aKoffuor GA, Woode E, Mensah AY. Neurobehavioural and safety evaluation of a polyherbal antihypertensive mixture in Ghana. Euro. J. Exp. Bio., 2011;1(3):20-30.

37. Podell M. Tremor, fasciculations, and movement disorders. Vet Clin Small Anim. 2004;34:1435-52.

38. MediaLab Incorporated, Urine Information and Courses from MediaLab, Inc. 2013. .Available at: http://www.medialabinc.net/urine-keyword.aspx. Accessed 22 June, 2013.

39. Talarico LD. Myeloproliferative disorders: A practical review. Patient Care. 1998;30:37-57.

40. França RT, Da Silva AS, Costa MM, Paim FC, Soares JF, Labruna MB, et al. Hematologic and bone marrow changes in dogs experimentally infected with Rangelia vitalii. Vet Clin Pathol., 2013;42(1):31-9.

41. Pincus MR and Abraham NZ. Interpreting laboratory results. In: McPherson RA, Pincus MR, eds. Henry's Clinical Diagnosis and Management by Laboratory Methods. 22nd ed. Philadelphia, Pa: Saunders Elsevier; 2011.

42. bKoffuor GA, Woode E, Obirikorang C, Asiamah E. Toxicity Evaluation of a Polyherbal Antihypertensive Mixture in Ghana. Journal of Pharmacy and Allied Health Sciences 2011;1(2):34-8. 
43. Phillips JE, Best MA. Liver function tests. 2013. Available http://www.surgeryencyclopedia.com/La-Pa/LiverFunction-Tests.html. Accessed 22 June 2013. doi:10.5455/2319-2003.ijbcp20131003

Cite this article as: Koffuor GA, Ainooson GK, Addotey JNA, Amponsah IK, Afriyie VA, Tutu R. Preliminary pharmacological investigation of the ischuretic property and safety of a hydro-ethanolic extract of Amaranthus spinosis (Fam:

Amaranthaceae). Int J Basic Clin Pharmacol 2013;2:517-27. 